\title{
Interactive Television Versus Traditional Lecture Teaching Methods Among Saudi Arabian Undergraduate Students
}

\author{
Safaa A. Zahran*
}

\begin{abstract}
Technology-facility collaboration is being widely deployed in modern classrooms. The Strategy of Saudi Arabia universities is using interactive television technology, while engaging students at distance education. This study is designed to investigate the students' opinions about interactive television method versus traditional lecture as a mean of delivery for undergraduate students' courses. This study conducted in Community College, affiliated to King Abd-El Aziz University. Student Evaluation of Teaching Questionnaire was used to assess the opinion of the sample of undergraduate students in the last academic year. This study shows that while students have accepted interactive television method, most students strongly preferred the traditional lecture method to teach courses. Some problems were evidenced in that new method. Lecturer's inability to manage class environment, lacking experience lecturer, and unavailability of in time of exam, were the most statistically significant students' problems. Interactive television teaching method in Saudi Arabian university classes is newly introduced method for teaching of only some subjects. Accordingly, it is recommended that faculty put into consideration to select effective teaching strategy particularly suitable for such settings and those specific groups of Saudi Arabian students.
\end{abstract}

\section{INTRODUCTION}

Interactive television (two-way) allows established in virtually all levels of linkage of traditional "on campus" classes education because of its ability to serve with nontraditional classes "remote". It also increased numbers of students, especially has the additional advantage of preserving in remote class (nontraditional). The term real-time interaction between students and distance education arose from the situation lecturer.(1) Distance education is where students were receiving instruction 
at a site physically separate from the lecturer. With the advent of distance learning technologies the challenge to the faculty is to create a connected class without being physically present.(2) Growth in distance education has become more widespread across multi-campus universities, particularly in large introductory classes or in specialized subjects. ${ }^{(3)}$ Lecturers in most interactive television method are non-interactive, talking most of the time and at best asking a few questions.

Charlton (2006) ${ }^{(4)}$ reported that lectures retain to be the best educational teaching method. Because of its exploit evolved human psychology that make learning easier and more effective. Interactive television cannot replace the traditional classroom. But it is a good alternative in distance learning to facilitate instruction, develop learners, and providing the potential for academic success. Interactive television environment is most closely resembles to a traditional classroom. ${ }^{(5)}$

Nowadays, the same university uses the two methods side by side. University can link classrooms traditional lecture with interactive television method, according to its institutional functions. The university has made it possible for distance students to enroll in the same course, following the same programme, be assisted by the same lecturers and obtaining the same qualifications. Also the same lecturer divides his time regularly between internal and external students. University lecturers perform all the same functions for both distance and lecture students, except other functions peculiar to the duties of a distance education. ${ }^{(6)}$

The university proposed distance model is based on the idea that distance teaching should originate within traditional universities. Aiming to reorganize providing an adequate response to the qualitative and quantitative need for education. Beside the goal of flexibility, diversification and 
internationalization of teaching-learning processes. $^{(6)}$ Halabi, et al., $\quad(2000)^{(3)}$ expressed the fundamental reasons for implementing interactive television, as to be the economic factor and the student load factor that drove the introduction of interactive television between the two studied campuses in his research.

At the beginning the distance education was one-way audio and one-way video, this is a passive medium convert students responses to questions or situations. The interactive television learning developed to be participative and always involves two-way audio and oneway video. Now the modern interactive television involves two-way audio and twoway video. ${ }^{(7)}$ The most resent distance education method is teaching on live interactive television. $(4,5)$ Through two-way video and two-way audio technology, the lecturer and learner can see and hear each other in real time. Experts agree that distance education is a cost-effective method of providing instruction with comparable learning out comes. ${ }^{(8)}$ The educator concern is how to use lecture methods (lecturer-centered, interactive, individualized, and experiential) effectively and efficiently within a course and within the interactive television lecture. ${ }^{(7)}$

A learner-centered teaching style is said to be most effective in promoting understanding and comprehension. The studies on lecturer-student interaction identified the acclimation of students to the technology and the creation of a comfortable environment. The lecturer's strategies should include the integration of interactive activities to encourage students' interaction. ${ }^{(5,9)}$ Although the advances in communication and evolution of distance learning, some studies believe that interaction is the most important instructional element in distance learning. They believe that interaction is the most important learning and that a high level of interaction makes distance courses more 
effective..$^{(5,6,10)} \quad$ Dupin-Bryant $(2004)^{(10)} \quad$ with two sites of students, e.g., by using contends that the amount of interaction appropriate camera eye contact and among students in a distance learning managing student use of microphones on course is an indicator of successful the two groups. ${ }^{(3,11)}$

learning experiences and increases

Evaluation of faculty performance student achievement and satisfaction. The includes self-evaluation, expert review of live and visual elements in interaction teaching materials, peer review, and television provide a good medium for interaction in distance learning.

student evaluation. Self-evaluation and expert review have been criticized as

Experienced distance lecturers have subjective assessments. Peer-review is offered valuable suggestions, methods, episodic and subject to the Hawthorne and strategies to bridge the physical effect. Student evaluations of faculty are separation between lecturer and learner. the most common form of systematic Educator compensation and workload evaluation and are typically required by adjustment are frequently their concerns.(8) universities across all types of delivery The lecturer has to learn how to teach a system. Student's ratings are reliable, course on television, how to design and implement the multimedia products and how to create an interactive teaching site valid, and stable over time. ${ }^{(8)}$

\section{Aim of the study}

This study is designed to investigate on. ${ }^{(4,8)}$ Lecturer needs to become familiar undergraduate students' opinions with new equipment (camera, microphone, regarding interactive television versus television, monitor,...,etc.), software, traditional lectures, and their preferences, material preparation, clothing and dealing as well as obstacles for interactive 
television teaching.

MATERIAL AND METHODS

Design: a descriptive design.

Setting: The study was conducted in Community College, Tabouk, affiliated to King Abd-El Aziz University, Saudi Arabia. The girls department in the university used the distance education when the lecturer is male educator.

Subjects: The sample consisted of all undergraduate students (100 students) in the last academic year. Ten students were excluded for pilot study. Some students lost from questionnaire (6 students). The total sample was 84 female students in the last semester. The students were studying in science departments "Medical records and Computer sciences". Students were studying by both types of education, traditional "lecture" and interactive television.

\section{Tools:}

Tool 1:
Modified Student Evaluation of Teaching Questionnaire by Fetzer $(2000)^{(8)}$. It was used to collect the following data from the students:

a- Demographic characteristic of subject includ age and department.

b- Students' opinion about interactional television method versus traditional method "lecture". It is composed of 12 questions for each specific item, scored on 5-points Likert scale. It is designed as strongly agree (5) to strongly disagree (1).

c- One question about educational methods they preferred.

d- Obstacles related to interactive television teaching.

Tool 2:

Observation sheet, developed by researcher based on the review of literature to assess.

(1): Classroom setting including items on televisions, student' seats, microphones, 
cameras.

(2): Studio setting including items on control system, PC, speakers, microphone, camera, projector, telephone.

\section{Methods:}

The tools were examined for content validity, visibility and utility by 5 lecturers in education. A pilot study was carried out on ten students (who were excluded from the study), to assess the clarity of questionnaire and to identify difficulties that may be faced during data collection. A permission to conduct the study was obtained from the Dean of college. Students completed a questionnaire (tool 1) in the college to determine students' opinions about teaching methods.

\section{Statistical analysis:}

Data were collected, coded, and organized into tables and then analyzed using the Statistical Package for Social Sciences (SPSS). Descriptive measures, including frequency, percentage, arithmetic mean and standard deviation were presented. Z tests were used for statistical correlation. A P value was statistically significant at level $0.05 \%$. Ranking of obstacles was also done.

\section{Results}

The result of the present study showed that the interactive television classroom was a large classroom located at the college main campus, it has four televisions. The students sat in rows, as well as several microphones installed in the wall "intercoms" for students to communicate with the lecturer. This class was controlled by assistant lecturer or supervisor. The male lecturer set in the studio, which was in the special building of the college main campus; there was one interactive television control system. This system contains one PC with two speakers, one microphone, camera, one document projector, one telephone. This system involves two-way audio and oneway video "the lecturer can't see the students". 
Table 1 shows the demographic characteristics of the students. The student's age ranged between $20-24$ years. Sixty two percent of the students were in the age group ranging between 22 to less than 24 years. The students $60.71 \%$ were studying in computer science department and $39.29 \%$ were studying in medical record department.

The mean and score of a student opinion about interactive television and traditional lecture is presented in table 2. The table presents the items of objectives clearly presented had the highest mean (3.85) for interactive television method. But the item of lecturer - student interaction has the highest mean (4.66) for traditional method. On the other hand, the least score was presented material effectively in interactive television method mean (2.14) and in traditional lecture was grading described to students mean (2.28). Analysis of result indicated that difference was significant in seven items including; well-prepared for class, presented material effectively, encouraged discussion, lecturer available outside of class, grading described to students, graded in fair manner and lecturer-student interaction at $\mathrm{P}<0.05 \%$.

In table 3, students' preference concerning the traditional and interactive television methods indicates that most students $(69.05 \%)$ prefer traditional teaching method lecture in both departments "medical record $27.38 \%$ and computer sciences 41.66\%". The difference was statistically significant $[Z=$ 4.82, $\mathrm{P}<0.05]$.

The table 4 interactive television teaching obstacles were mentioned by students. The table revealed the lecturer Inability to manage class environment was among majority of student (70.23\%). On the other hand, more than half of students (55.95\%) cited the obstacle of inexperienced lecturer. Also the obstacle of lecturer not available in exam mentioned 
by $(41.66 \%)$ of students. Agreement of students for these obstacles were statistically significant difference at $[P=0.05 \%]$. Also other obstacles as nonprofessional assistance, time consuming, student-assistant relationship and poor feedback mentioned by $26.19 \%, 17.85 \%$, $9.52 \%$, and $4.76 \%$ percent of students, respectively.

\section{DISCUSSION}

The use of teaching strategies does not guarantee learning. By increasing an emphasis on student learning during teaching, and by listening to students through classroom assessment, improvements can be made. Classroom assessment clearly links teaching and learning. ${ }^{(12)}$

The present study revealed no statistical differences between interactive television and lecture method of teaching for basic several items. Whatever method of teaching used, the lecturers prepare the material carefully. Lecturers do the best for their course to be successfully taut to student. They present the course objective clearly. The course content and assignment were related to the objectives. It is apparent that the lecturer was fair in treating their student and if any question from any student they answer effectively. The present study identified in table 3 , a high proportion of students prefer traditional lecture (69.05\%). This result supported by Halaby et al., (2000)(3) study which found that four times number of students $(58.4 \%$ vs. $16 \%)$ did not enjoy interactive television as much as lecture sessions. Beeson and Kring (1999)(13) study showed students who were taught by the traditional lecture method gained significantly more factual knowledge than students taught by interactive television. Other studies noted that the students evaluation teaching using the traditional format were higher than average, indicating the faculty was proficient in the teaching role and course content. The findings 
suggest that when the same faculty teaches the same course to a similar population of students using interactive television systems, there is a negative impact on student evaluation of teaching, ${ }^{(14,15)}$ which is shown in this study.

From the results in table 2 , it is evident that the students' opinions about the misunderstanding of the lecturers usage of interactive television materials (mean $=2.14)$. It was due to untrained lecturers about this method. Royal and Bradly $(2005)^{(11)}$ study reported that many instructors have limited experience with distance-base instruction, when they used interactive television method. Also in other study, this item mentioned by $55 \%$ of students. ${ }^{(3)}$ In this study students thought traditional lecture was fairer than interactive television $($ mean $=3.64$ vs. 3.14 , respectively). In contrast, the results of other study noted that interactive television was fairer than lecture $(52.5 \%$ vs. $21 \%$, respectively). (3)
This study shows that student thought the interactive television method impact on their final grade $($ mean $=3.21$ ), but another study noted that most of students thought interactive television or lecture would have no different impact on their final grades. ${ }^{(3)}$ Another explanation of interactive television's ability to accommodate learning approaches which effectively involve students in distance learning courses. According to McKimmy study $(2005)^{(5)}$; the keys to effective distance education are learner-centered teaching styles that reduce the distance learners' psychological effect and increase student involvement in the teachinglearning process. Also, greater workload requirements and lack of financial and psychological recognition make interactive television teaching less than appealing. ${ }^{(8)}$

According to lecturer-student interaction, the present study revealed that it was greater in lecture method than interactive television method (means = 
4.66 and 3.35, respectively). Anderon and Kent (2000) ${ }^{(16)}$ study demonstrated higher levels of interaction lead to greater student performance. In other studies, they concluded that interactive television students were generally satisfied because the interaction between faculty and students were enough to facilitate learning. ${ }^{(17,18)}$ These differences presented because King Abd-El-Aziz University used two-way audio and one-way video system "the lecturer can't see the students", but in the other study the university use two-way of communications.

Also, Wokott $\quad(2003)^{(19)} \quad$ study suggested that the key element in the development of international educational experiences through distance technologies is access to technology and technological support. In other words, the microphones and cameras at the receiving end pick up the sound and image back to lecturer's classroom, which affect on lecturer- students interaction. (2) Halabi, et al., (2000) (3), explained in such environments the lecturer and students are on different campuses and the technology does not support the same level of easy facilitation of turn-taking and coordination as face-toface lecture.

A variety of instructional strategies that could be used to increase and improve interactions within a distance education environment by involving the student in viewing, listening, writing, reading, speaking and combinations of them. Involvement requires careful planning and time control, if it occurs in a live distance education. The use of pre-class activities has been shown to be an effective method in both live programs. Coupled with effective questioning strategies, these interactive methods can be used to broaden the scope of interactive television.

(7) Communication between the lecturer and the students during a lecture was 
encouraged by frequent questions. He also encouraged the students to ask questions. ${ }^{(3)}$

Lectures are probably the best teaching method in many circumstances and for many students, especially for communicating conceptual knowledge. Lectures are effective because they exploit the spontaneous human attitude for spoken communications and because they are real-time, human-presence social events. All communication technologies are artificial and unnatural; this is probably why many students find it easier to learn from lectures than from media. The second reason for lectures' effectiveness that they are formally-structured social events with artificially manipulate human psychology. A formal lecture is a mutually-beneficial between class and lecturer, to improve learning. (4)

Also, Calder (2007)(20) suggested that students are likely to rate interactive television instructors lower than instructors in a lecture, and this agrees with my result. Also the result supported by other study which noted that, there was a significant group effect, $F(1,102)=P \quad 0.01$, for teaching method. Students taught by the traditional lecture method $(\mathrm{M}=92.43)$ gained significantly more factual knowledge than students taught by interactive television ( $M=88.30)$. (13) While another study reported that teaching evaluations of interactive television lecturers showed little deference from typical evaluations, and students' attitudes toward the delivery method were generally positive. $(1,11)$ These results were due to the taken courses by students about interactive television in the past, so they became more comfortable.

A number of obstacles were encountered which would not have been evident in lectures. These concerned the connection problems, time delay in transmission of materials, and staff student interaction in lectures. ${ }^{(3,14)}$ The present 
study identified in table 4 the interactive television obstacles mentioned by students were according to the responsibilities of lecturer to mange the lecture, his experience and unavailability in time of exam. These obstacles correlated to the fact that generally there is only one-way video and two-way audio for interaction. Halabi, et al., (2000) (3) supported the present study result and mentioned that $25 \%$ of students stated interactive television led to a lack of communication between staff and students, and an inability to ask questions. However, student feel the disadvantages of interactive television, such as a reduction in learning time, increased potential for disruptive behavior, reduction in access to lecturers. Also it was found that students at remote sites did not feel part of the lecture, and experienced a reduced concentration span. ${ }^{(3,14)}$ However, a different lecturer was responsible for each delivery system and variability of teaching style may have contributed to the differences between groups.

\section{CONCLUSION}

It can be concluded from the present study that most students preferred the traditional lecture approach to teaching courses than interactive television. Lecturer performance effect on the teaching method, and most obstacles mentioned by students were according to their lack of experience to mange the lecture.

\section{RECOMMENDATIONS}

Based on the findings of the present study, the following recommendations are suggested:

- Enhancing of the lecturer's efficiency by training on using the distance education method to manage the lecture environment and to improve the interaction with students.

- The university should promote flexible learning and support the lecturer administratively. 
- The university should improve different teaching programs, and efficient use of technology.

- Developing the teaching methods by using the two-way method of distance education and internet to gain more effective learning.

- Development of the students' preparation for guaranteeing their satisfaction in taking the distance course.

Table 1: Distribution of students according to their demographic characteristics. $(n=84)$

\begin{tabular}{|l|c|c|}
\hline \multicolumn{1}{|c|}{ Variable } & No. & $\%$ \\
\hline Age in years: & 12 & 14.29 \\
$20-$ & 52 & 61.90 \\
$22-$ & 20 & 23.81 \\
\hline $24+$ & 33 & 39.29 \\
\hline Departments: & 51 & 60.71 \\
\hline Medical Record & & \\
Computer science & \multicolumn{2}{|l}{} \\
\hline
\end{tabular}


Table 2: Total scores and mean for students' opinions questions about interactive television and traditional teaching methods. $(n=84)$

\begin{tabular}{|c|c|c|c|c|c|c|c|}
\hline \multirow{3}{*}{ Evaluation Criterion } & \multicolumn{6}{|c|}{ Student opinion } & \multirow{3}{*}{$\mathbf{P}$} \\
\hline & \multicolumn{3}{|c|}{ Interactive Television } & \multicolumn{3}{|c|}{ Traditional Lecture } & \\
\hline & $\begin{array}{l}\text { Total } \\
\text { Score }\end{array}$ & Mean & S.D & $\begin{array}{l}\text { Total } \\
\text { Score }\end{array}$ & Mean & S.D & \\
\hline Objectives clearly presented & 324 & 3.85 & 0.98 & 344 & 4.09 & 0.95 & 0.091 \\
\hline Content related to objectives & 318 & 3.78 & 1.03 & 282 & 3.35 & 1.13 & 0.072 \\
\hline Well-prepared for class & 240 & 2.85 & 0.99 & 380 & 4.52 & 0.94 & $0.001^{*}$ \\
\hline Presented material effectively & 180 & 2.14 & 0.87 & 330 & 3.92 & 1.03 & $0.0136^{*}$ \\
\hline $\begin{array}{l}\text { Encouraged discussion } \\
\text { questions }\end{array}$ & 276 & 3.28 & 1.03 & 366 & 4.35 & 0.94 & $0.021^{*}$ \\
\hline Answered questions effectively & 318 & 3.78 & 1.22 & 336 & 4.00 & 0.78 & 0.079 \\
\hline Fair with students & 269 & 3.14 & 1.09 & 306 & 3.64 & 1.08 & 0.168 \\
\hline $\begin{array}{lll}\begin{array}{l}\text { Assignments } \\
\text { objectives }\end{array} & \text { related } & \text { to } \\
\end{array}$ & 246 & 2.92 & 0.94 & 198 & 2.35 & 1.21 & 0.21 \\
\hline $\begin{array}{l}\text { Lecturer available outside of } \\
\text { class }\end{array}$ & 270 & 3.21 & 1.25 & 366 & 4.35 & 0.86 & $0.041^{*}$ \\
\hline Grading described to students & 318 & 3.78 & 1.36 & 192 & 2.28 & 1.25 & $0.039^{*}$ \\
\hline Graded in fair manner & 270 & 3.21 & 1.52 & 344 & 4.09 & 0.77 & $0.049^{*}$ \\
\hline Lecturer-student interaction & 282 & 3.35 & 1.33 & 392 & 4.66 & 0.69 & $0.011^{*}$ \\
\hline
\end{tabular}

*Statistically Significant

Table 3: Students' preferences concerning the traditional and interactive television methods. $(n=84)$

\begin{tabular}{|l|c|c|c|c|c|c|}
\hline \multirow{2}{*}{ Department } & \multicolumn{2}{|c|}{ Traditional lecture } & \multicolumn{2}{|c|}{ Interactive television } & \multirow{2}{*}{ Z } & \multirow{2}{*}{$\mathbf{p}$} \\
\cline { 2 - 5 } & No. & $\%$ & No. & $\%$ & & \\
\hline Medical Record & 23 & 27.38 & 10 & 11.90 & & \\
\hline Computer Science & 35 & 41.66 & 16 & 19.05 & \multirow{2}{*}{4.82} & \multirow{2}{*}{$0.0025^{*}$} \\
\hline Total & 58 & 69.05 & 26 & 30.95 & & \\
\hline
\end{tabular}

${ }^{*}$ Statistically Significant 
Table 4: Identification of interactive television obstacles mentioned by students.

$(\mathrm{N}=84)$

\begin{tabular}{|l|c|c|c|l|}
\hline Obstacles & $\begin{array}{c}\text { No. of } \\
\text { student }\end{array}$ & $\%$ & $\begin{array}{c}\text { Ranking of } \\
\text { Obstacles }\end{array}$ & \multicolumn{1}{|c|}{ Sign. } \\
\hline Lack of experienced lecturer & 47 & 55.95 & 2 & $0.032^{*}$ \\
\hline Non-professional assistance & 22 & 26.19 & 4 & 0.11 \\
\hline Inability to mange class environment & 59 & 70.23 & 1 & $0.0016^{*}$ \\
\hline Unavailability in time of exam & 35 & 41.66 & 3 & $0.041^{*}$ \\
\hline Time consuming & 15 & 17.85 & 5 & 0.11 \\
\hline Student-assistant relationship & 8 & 9.52 & 6 & 0.29 \\
\hline Poor feedback & 4 & 4.76 & 7 & 0.61 \\
\hline
\end{tabular}

*Statistically Significant

\section{REFERENCES}

1. Andrews E, Gosse V, Gaulton R, Maddigan R. Teaching Introductory Psychology at a Distance by Two-Way Interactive Video. Teaching of Psychology, 1999; 26. Available from: http//www.mhtml/F/education/pdffiles. Accessed at. May 2008.

2. Chandler G, Hanrahan P. Teaching Using Interactive Video: Creating Connections. Journal of Nursing Education. 2000; 39 (2): 73-80.

3. Halabi A, Tuovinen J, Maxfield J. Evaluation of Education Interactional in Accounting Tele-Teaching.Revew of Educational Research. 2000; 53 (4): 445-61.

4. Charlton BG. Lectures are an Effective Teaching Method because They Exploit Human Evolved' Human Nature' to Improve Learning. Medical Hypotheses. 2006; 67: 1261-5.

5. McKimmy P. Interactive in ITV: An Instructional Module for Faculty Teaching via Interactive Television. Master in education, Hawaii University, 2005.Available from: http//www.mhtml/F/education/pdffiles adobe/acrobat. Accessed at. Des 2008.
6. Amata G. The Television University New Models of Distance Teaching and Learning. Online Educa Berlino- $5^{\text {th }}$ International Conference on Technology Supported Learning, 1999; Nov.:24-26.

7. Cyrs T, Smith F. Maximizing Interaction During a Telecourse. Teleclass Teaching. New Mexico State University, Las Cruces,1990. Available from: http// www.mhtml/F/education/pdffiles. Accessed at. April 1999.

8. Fetzer S. A Pilot Study to Investigate the Impact of Interactional Television on Student Evaluation of Faculty Effectiveness. Journal of Nursing Education. 2000; 39 (2): 91-3.

9. Mash R, Marais D, Steyn M. Assessment of the Quality of Interaction in Distance Learning Programmes. Medical Education. 2005; 39 (11): 1093-100.

10. Dupin-Bryant P. Teaching Styles of Interactive Television Instructors. The American Journal of Distance Education. 2004; 18 (1): 139-50.

11. Royal K, Bradly K. Interactive Television (ITV) Courses and Students' Satisfaction. Online Journal of Distance Learning Administration. 
2005; 8(6). Available at: http:www.westge,edu/distance/ojdla/ht $\mathrm{m}$.

12. Melland H, Volden C. Classroom Assessment: Linking Teaching and Learning. Journal of Nursing Education. 1998; 37 (6): 275-7.

13. Beeson S, Kring D. The Effects of Two Teaching Methods on Nursing Students' Factual Knowledge and Performance of Psychomotor Skills. Journal of Nursing Education. 1999; 38 (8): 357-9.

14. Iwasiw $C$, Moen $A$, Stovring $T$. Graduate Education in Nursing Leadership through Distance Technologies: The Canada-Norway Nursing Connection. Journal of Nursing Education. 2000; 39 (2): 81-5.

15. Liu Y. Distance and Traditional Education Teaching the Same via Instructional Television and Traditional Educational Format. Online Journal of Distance Learning Administration,2002; 3(1). Available from: http:www.westge,edu/distance /ojdla/htm.
16. Anderson L, Kent A. Interactive Televised Courses. College Teaching. 2002; 50 (2), 1-8.

17. Clow K. Interactive Distance Learning: Impact on Student Course Evaluations. Journal of Marketing Education. 1999; 21(2): 97-106.

18. Royal K, Bradley K, Lineberry T. Evaluating Interactive Television (ITV) Courses. Online Journal of Distance Learning Administration, 2005; 8(6). Available from: http:www.westge,edu/distance/ojdla/ht $m$.

19. Wolcott L. Faculty Planning for Distance Teaching. The American Journal of Distance Education. 2003; 7 (1): 26-33.

20. Calder C. A comparison of Four Methods of Teaching Psychomotor Activities to Elementary School Children from Varying Socioeconomic Levels. Educational Technology Research and Development. 2007; 18(1): 12-119. 